\title{
Fluoride Processing of Titanium-Containing Minerals
}

\author{
N. M. Laptash, I. G. Maslennikova \\ Institute of Chemistry, Far Eastern Branch of RAS, Vladivostok, Russia \\ Email: laptash@ich.dvo.ru \\ Received 2012
}

\begin{abstract}
Fluoride processing of natural ilmenite with the use of ammonium hydrogen difluoride $\left(\mathrm{NH}_{4} \mathrm{HF}_{2}\right)$ as an effective fluorinating agent is suggested. Chemistry, composition, structure, thermal and hydrolytic properties of fluorination products were investigated. Ammonium fluoro- and oxofluorotitanates are suitable for preparing of titanium dioxide as pigmentary product or as doped by nitrogen and fluorine.
\end{abstract}

Keywords: Ilmenite; Fluorination Reactions; Ammonium Hydrogen Difluoride; Ammonium Fluoro- and Oxofluorometallates; Thermal Behavior; Hydrolysis; N-F-TiO 2 .

\section{Introduction}

Titanium dioxide $\left(\mathrm{TiO}_{2}\right)$ has long been at the center of photocatalyst research due to its catalytic efficiency coupled with wide availability, biocompatibility, chemical stability, low cost, and safety toward both humans and the environment. It is much more effective as photocatalyst in the form of nanoparticles modified by doping with cations and anions [1,2]. The nitrogen and fluorine-doped titanium dioxide $\left(\mathrm{N}-\mathrm{F}-\mathrm{TiO}_{2}\right)$ nanomaterials exhibit high photocatalytic activity for water-splitting and photodegradation of organic pollutants [3-8]. It was shown that co-doping with nitrogen and fluorine is advantageous for the reduction of defect formation and lowers the energy cost for the incorporation of nitrogen owing to the charge compensation effect between the donor (F) and acceptor (N) [9].

Multifunctional properties and vast applications of nano$\mathrm{TiO}_{2}$ require its production in a mass scale. The large-quantity production of rutile nanorods from ilmenite sands was recently suggested $[10,11]$. Ilmenite $\left(\mathrm{FeTiO}_{3}\right)$ is abundant feedstock for industrial production of $\mathrm{TiO}_{2}$. At present, ilmenite is commonly used in industry for making white pigment via a sulfate or chlorine route having serious disadvantages, such as the treatments of byproducts in the former and the lack of raw rutile minerals in the latter. Fluoride processing of titanium-bearing minerals can serve as an alternative. Ammonium hydrogen difluoride $\left(\mathrm{NH}_{4} \mathrm{HF}_{2}\right.$, solid, melting point is $126^{\circ} \mathrm{C}$, boiling point is $240^{\circ} \mathrm{C}$ ) was recognized as versatile fluorinating agent for recovering of titanium-containing raw materials [12,13]. It should be noted that foundation of ilmenite processing with ammonium hydrogen difluoride was created by Svendsen as early as the thirties $[14,15]$. The suggested methods comprised fluorination with molten $\mathrm{NH}_{4} \mathrm{HF}_{2}$ followed by sublimation of fluoride titanium compound but the detailed chemistry was not completely understood. Since the fluorination products are ammonium fluoroor oxoflluorotitanates, it is reasonable to consider them as precursors for the $\mathrm{N}-\mathrm{F}-\mathrm{TiO}_{2}$ obtaining.

Indeed, the $\mathrm{N}-\mathrm{F}-\mathrm{TiO}_{2}$ nanoparticles of anatase crystalline structure were recently prepared by a facile method of $\left(\mathrm{NH}_{4}\right)_{2} \mathrm{TiF}_{6}$ pyrolysis [16]. The synthesis of $\mathrm{N}-\mathrm{F}$-codoped $\mathrm{TiO}_{2}$ powders with a homogenous anatase structure via a thermal decomposition of different ammonium oxofluorotitanate precursors at $550^{\circ} \mathrm{C}$ was reported [17]. Uniform ammonium oxofluorotitanate $\left(\mathrm{NH}_{4} \mathrm{TiOF}_{3}\right)$ mesocrystals and their conversion to mesocrystals of $\mathrm{TiO}_{2}$ were described [18-20]. Titanium oxyfluoride $\mathrm{TiOF}_{2}$ was synthesized for obtaining of thermally stable $\mathrm{TiO}_{2}$ of high photocatalytic activity [21] and for its use as anode material for lithium-ion battery [22]. The synthesis of the above precursors from natural ilmenite and investigation of their physicochemical properties is the aim of present paper.

\section{Fluorination of Ilmenite with $\mathrm{NH}_{4} \mathrm{HF}_{2}$}

Interaction of ilmenite with $\mathrm{NH}_{4} \mathrm{HF}_{2}$ proceeds exothermally at room temperature under grinding the initial components [23]. Similar reactions when two solids interact under mechanical grinding with the formation of a new compound were being studied by Indian authors since 1982 [24]. One should concentrate attention on nonstoichiometric composition of fluorinating products due to some $\mathrm{OH}^{-}$groups substituting for fluorine since water molecules are formed during fluorination:

$$
\begin{aligned}
& \mathrm{FeTiO}_{3}+(5-0.5 \mathrm{y}) \mathrm{NH}_{4} \mathrm{HF}_{2} \\
= & \mathrm{NH}_{4} \mathrm{H}_{2 \mathrm{x}} \mathrm{FeO}_{\mathrm{x}} \mathrm{F}_{3}+\left(\mathrm{NH}_{4}\right)_{3} \mathrm{Ti}(\mathrm{OH})_{\mathrm{y}} \mathrm{F}_{7-\mathrm{y}}+(1-0.5 \mathrm{y}) \mathrm{NH}_{3} \\
& +(3-\mathrm{x}-\mathrm{y}) \mathrm{H}_{2} \mathrm{O} \quad(\mathrm{x} \leq 0.3, \mathrm{y} \leq 0.4) .
\end{aligned}
$$

The main titanium fluoride product is a double salt isostructural with $\left(\mathrm{NH}_{4}\right)_{3} \mathrm{TiF}_{7}=\left(\mathrm{NH}_{4}\right)_{2} \mathrm{TiF}_{6} \cdot \mathrm{NH}_{4} \mathrm{~F}$ which was isolated in a single crystal form from fluoride aqueous solution. Its crystal structure was determined. The parameters of tetragonal unit cell were changed under X-rays, the stable phase is characterized by the following parameters: sp. gr.P4nc; a $=11.97$, $\mathrm{b}=11.68 \AA ; \mathrm{z}=8$. One of the three independent Ti octahedra is disordered so a phase transition (PT) at about $280 \mathrm{~K}$ takes place. $\mathrm{Fe}(\mathrm{II})$ forms a cubic fluoroperovskite type structure and easily oxidized in air and in aqueous solution, and Fe(III) fluoride compound crystallizes in cubic fluoroelpasolite structure. Its octahedral single crystals of the $\left(\mathrm{NH}_{4}\right)_{\mathrm{x}} \mathrm{Fe}(\mathrm{OH})_{3-\mathrm{x}} \mathrm{F}_{2 \mathrm{x}}$ ( $\mathrm{x}=$ 2.70-2.85) composition were grown. Usually, natural ilmenite 
contains some $\mathrm{Fe}(\mathrm{III})$. We dealt with the real composition of $0.8 \mathrm{FeTiO}_{3} \cdot 0.1 \mathrm{Fe}_{2} \mathrm{O}_{3}$ and investigated carefully its fluorinated process. The corresponding thermal curves are shown in Figure 1. An exoeffect at $125^{\circ} \mathrm{C}$ is evident.

The corresponding equation can be expressed as follows:

$$
\begin{aligned}
& 0.8 \mathrm{FeTiO}_{3} \cdot 0.1 \mathrm{Fe}_{2} \mathrm{O}_{3}+4.4 \mathrm{NH}_{4} \mathrm{HF}_{2} \\
= & 0.8 \mathrm{NH}_{4} \mathrm{H}_{0.4} \mathrm{FeO}_{0.2} \mathrm{~F}_{3}+0.2\left(\mathrm{NH}_{4}\right)_{2.8} \mathrm{Fe}(\mathrm{OH})_{0.2} \mathrm{~F}_{5.6} \\
+ & 0.8\left(\mathrm{NH}_{4}\right)_{3} \mathrm{Ti}(\mathrm{OH})_{0.4} \mathrm{~F}_{6.6}+0.64 \mathrm{NH}_{3}+2.18 \mathrm{H}_{2} \mathrm{O} .
\end{aligned}
$$

The endoeffect at $280^{\circ} \mathrm{C}$ corresponds to thermal decomposition of titanium double salt. Further effects are connected with thermal behavior of $\left(\mathrm{NH}_{4}\right)_{2} \mathrm{Ti}(\mathrm{OH})_{0.4} \mathrm{~F}_{5.6}$ and ammonium fluoroferrates:

$$
\begin{gathered}
\left(\mathrm{NH}_{4}\right)_{3} \mathrm{Ti}(\mathrm{OH})_{0.4} \mathrm{~F}_{6.6}=\left(\mathrm{NH}_{4}\right)_{2} \mathrm{Ti}(\mathrm{OH})_{0.4} \mathrm{~F}_{5.6}+\mathrm{NH}_{3}+\mathrm{HF} \\
\left(\mathrm{NH}_{4}\right)_{2.8} \mathrm{Fe}(\mathrm{OH})_{0.2} \mathrm{~F}_{5.6}=\mathrm{FeF}_{2}+0.17 \mathrm{~N}_{2}+2.47 \mathrm{NH}_{3} \\
+3.6 \mathrm{HF}+0.2 \mathrm{H}_{2} \mathrm{O} \\
\mathrm{NH}_{4} \mathrm{H}_{0.4} \mathrm{FeO}_{0.2} \mathrm{~F}_{3}=\mathrm{FeF}_{2}+\mathrm{NH}_{3}+\mathrm{HF}+0.2 \mathrm{H}_{2} \mathrm{O} \\
\left(\mathrm{NH}_{4}\right)_{2} \mathrm{Ti}(\mathrm{OH})_{0.4} \mathrm{~F}_{5.6}=\mathrm{NH}_{4} \mathrm{TiO}_{0.4} \mathrm{~F}_{4.2}+\mathrm{NH}_{3}+1.4 \mathrm{HF} \\
\mathrm{NH}_{4} \mathrm{TiO}_{0.4} \mathrm{~F}_{4.2}=\mathrm{NH}_{4} \mathrm{TiO}_{0.4} \mathrm{~F}_{4.2} \uparrow \\
\mathrm{FeF}_{2}+\mathrm{NH}_{4} \mathrm{TiO}_{0.4} \mathrm{~F}_{4.2}=\mathrm{FeTiF}_{6}+\mathrm{NH}_{3}+0.2 \mathrm{HF}+0.4 \mathrm{H}_{2} \mathrm{O} \\
\mathrm{FeTiF}_{6}=\mathrm{FeF}_{2}+\mathrm{TiF}_{4} \uparrow .
\end{gathered}
$$

One should mention the evolution of volatile titanium fluoride compound $\mathrm{NH}_{4} \mathrm{TiO}_{0.4} \mathrm{~F}_{4.2}$ which sublimes incongruently with the formation, probably, of the titanium adduct with $\mathrm{NH}_{3}$. We succeeded in obtaining of single crystal of this volatile compound and determined its chain structure (Figure 2). Infinite chains of cis-connected $\left[\mathrm{TiF}_{6}\right]$-octahedra are joint via $\mathrm{NH}_{4}$ groups by $\mathrm{N}-\mathrm{H} \cdots \mathrm{F}$ hydrogen bonds with the average $\mathrm{N} \cdots \mathrm{F}$ distance of 2.85-2.98 $\AA$ [25]. It is necessary to take into account that some $\mathrm{Ti}^{4+}$ is reduced to $\mathrm{Ti}^{3+}$ by $\mathrm{NH}_{3}$ evolved, so we used simple aqueous leaching of the cake to separate titanium from iron. One can expect the formation of ammonium oxofluorotitanate $\left(\mathrm{NH}_{4}\right)_{3} \mathrm{TiOF}_{5}$ at this stage at $\mathrm{pH}=7-8$ [26]. This compound is isostructural with iron fluoroelpasolite, their crystal structures were determined [27].

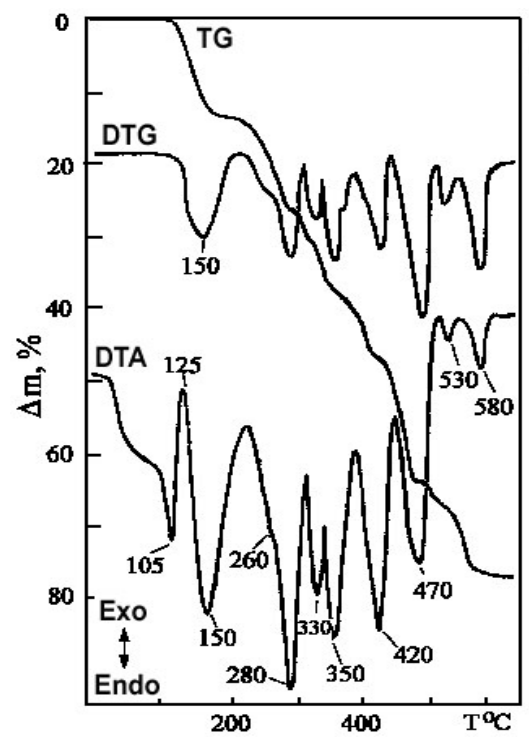

Figure 1. Thermal curves of the mixture of ilmenite with $\mathbf{N H}_{4} \mathbf{H F}_{2}$.

\section{Dynamic Orientational Disorder in Crystals of Iron and Titanium Fluoroelpasolites}

Classical cubic structure of $\mathrm{A}_{2} \mathrm{BMX}_{6}(\mathrm{~A}>\mathrm{B})$ elpasolite (Fm3m, $Z=4$ ) comprises a central atom $M$ to be in the 4 a position, ligands in 24e, larger cations in $8 \mathrm{c}$, and smaller cations in $4 \mathrm{~b}$. $\mathrm{NH}_{4}$ in the latter position is accepted to be disordered on two orientations. We advanced in the refining of this structure and published recently the paper on this subject [28]. In fact, the ligand atoms are distributed on mixed $24 \mathrm{e}+96 \mathrm{j}$ positions, and ammonium group in the $4 \mathrm{~b}$ position is distributed on the $32 \mathrm{f}$ position taking 8 equivalent orientations. Ammonium groups in the $8 \mathrm{c}$ position are tetrahedrally shifted into the $32 \mathrm{f}$ position. In the Ti oxofluoroelpasolite, a central atom is disordered on 6 orientations. The $\mathrm{Ti}$ atom is shifted towards the $\mathrm{O}$ atom with the formation of short triple Ti-O bond that allows to determine the real geometry of $\mathrm{TiOF}_{5}$ octahedron. Figure 3 presents disordered structure of the discussed elpasolites.

The observed disorder has a dynamic nature that the NMR data support (Figure 4). Two phase transitions at lower temperature are evident. The $\mathrm{M}_{2}$ jump at $265 \mathrm{~K}$ coincides with the temperature of phase transition (PT) detected by the differential scanning microcalorimetry method (DSM). The rather large value of entropy change $\Delta \mathrm{S}$ at this PT $\left(18.1 \mathrm{~J} \mathrm{~mol}^{-1} \mathrm{~K}^{-1}\right.$ or Rln9) characterizes this first order PT as of order-disorder type [29]. High anionic and cationic mobility is reflected in thermal behavior of this complex. The easy transfer of hydrogen from ammonium group to the $\mathrm{O}$ atom emerges in the IR spectrum as the appearance of strong hydrogen bond of the $\mathrm{O}-\mathrm{H} \cdots \mathrm{F}$ type at $700-800 \mathrm{~cm}^{-1}$. As a result, only $\mathrm{NH}_{3}$ and $\mathrm{H}_{2} \mathrm{O}$, but no $\mathrm{HF}$ evolve during the thermal decomposition of the compound.

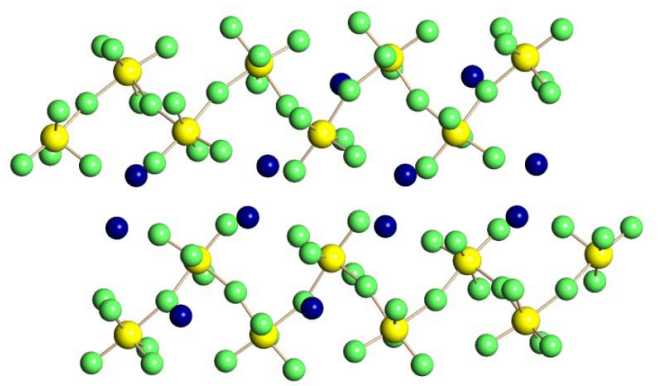

Figure 2. Crystal structure of $\mathrm{NH}_{4} \mathrm{TiO}_{\mathrm{x}} \mathrm{F}_{5-2 \mathrm{x}} \quad(\mathrm{x}=\mathbf{0 . 1 5})$ : sp. gr. $P 2{ }_{1} / n, \mathrm{a}=14.683, \mathrm{~b}=6.392, \mathrm{c}=20.821 \AA ; \quad \alpha, \gamma=90^{\circ}, \beta=110.538^{\circ}$, $\mathrm{Z}=\mathbf{1 6}$.

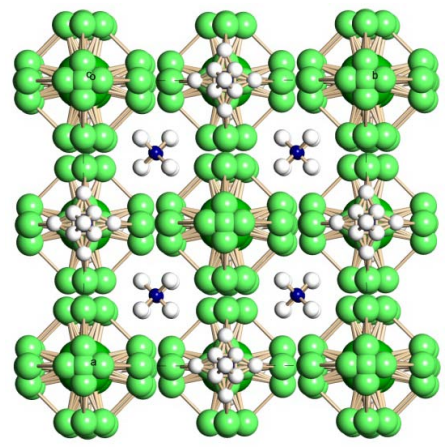

Figure 3. Disordered crystal structure of $\left(\mathrm{NH}_{4}\right)_{3} \mathrm{FeF}_{6}$ or $\left(\mathrm{NH}_{4}\right)_{3}$ $\mathrm{TiOF}_{5}$. 


\section{Thermal and Hydrolytic Properties of Ammonium Fluorometallates}

Thermal behavior of ammonium oxofluorotitanates were examined [30]. Thermal curves of the $\left(\mathrm{NH}_{4}\right)_{3} \mathrm{TiOF}_{5}$ decomposition are presented in Figure 5. The corresponding reactions can be expressed as follows:

$$
\begin{gathered}
2\left(\mathrm{NH}_{4}\right)_{3} \mathrm{TiOF}_{5}=\left(\mathrm{NH}_{4}\right)_{2} \mathrm{TiF}_{6}+\left(\mathrm{NH}_{4}\right)_{2} \mathrm{TiOF}_{4}+2 \mathrm{NH}_{3}+\mathrm{H}_{2} \mathrm{O}(10) \\
3\left(\mathrm{NH}_{4}\right)_{2} \mathrm{TiOF}_{4}=\left(\mathrm{NH}_{4}\right)_{2} \mathrm{TiF}_{6}+2 \mathrm{NH}_{4} \mathrm{TiOF}_{3}+2 \mathrm{NH}_{3}+\mathrm{H}_{2} \mathrm{O}(11) \\
4 \mathrm{NH}_{4} \mathrm{TiOF}_{3}=\left(\mathrm{NH}_{4}\right)_{2} \mathrm{TiF}_{6}+3\left(\mathrm{NH}_{4}\right)_{0.3} \mathrm{TiOF}_{2}+0.15 \mathrm{~N}_{2} \\
+0.8 \mathrm{NH}_{3}+\mathrm{H}_{2} \mathrm{O} .
\end{gathered}
$$

The process is accompanied by sublimation of volatile titanium compound and by the formation of hexagonal ammonium-containing $\mathrm{TiOF}_{2}$.

Hydrolysis process of volatile ammonium fluorotitanate, $\mathrm{NH}_{4} \mathrm{TiO}_{\mathrm{x}} \mathrm{F}_{5-2 \mathrm{x}}$, is practically important. Its aqueous solution has an acid reaction meaning the strong hydrolysis [31]. According to ${ }^{19} \mathrm{~F},{ }^{17} \mathrm{O}$, and ${ }^{49} \mathrm{Ti}$ NMR data, dimers with bridging $\mathrm{OH}$ or even trimers (cyclic or linear) are formed:

$$
\begin{aligned}
& \mathrm{NH}_{4} \mathrm{TiO}_{0.2} \mathrm{~F}_{4.6}+0.5 \mathrm{H}_{2} \mathrm{O}=0.25\left(\mathrm{NH}_{4}\right)_{2}\left[\mathrm{TiF}_{6}\right] \\
& +0.1\left(\mathrm{NH}_{4}\right)_{3}\left[\mathrm{Ti}_{2}(\mathrm{OH}) \mathrm{F}_{10}\right]+0.15\left(\mathrm{NH}_{4}\right)_{1.3} \mathrm{H}_{1.7}\left[\mathrm{Ti}_{3}(\mathrm{OH})_{3} \mathrm{~F}_{12}\right] \\
& +0.025 \mathrm{H}_{2}\left[\mathrm{Ti}_{4}(\mathrm{OH})_{6} \mathrm{~F}_{12}\right], \quad
\end{aligned}
$$

Oligomerization (polymerization) is the main feature of pyrohydrolisis of ammonium fluorotitanates and fluoroferrates. Kinetic curves show that it takes about 40 min to convert ammonium fluorometallates to oxides [32,33]:

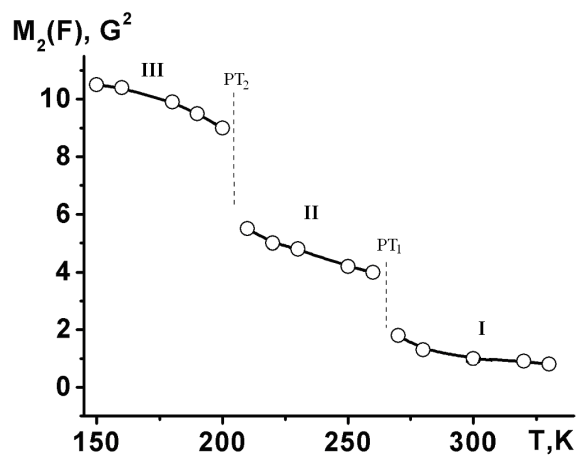

Figure 4. Temperature dependence of the second moment $\left(\mathrm{M}_{2}\right)$ of the ${ }^{19} \mathrm{~F}$ NMR spectrum of $\left(\mathrm{NH}_{4}\right)_{3} \mathrm{TiOF}_{5}$.

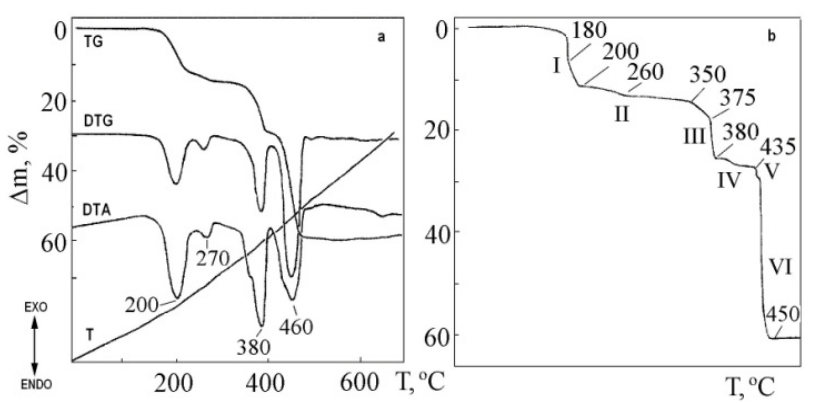

Figure 5. Thermal curves of $\left(\mathrm{NH}_{4}\right)_{3} \mathrm{TiOF}_{5}$.

$$
\begin{gathered}
\left(\mathrm{NH}_{4}\right)_{2} \mathrm{Ti}(\mathrm{OH})_{\mathrm{x}} \mathrm{F}_{6-\mathrm{x}} \rightarrow \mathrm{NH}_{4} \mathrm{TiOF}_{3} \rightarrow\left(\mathrm{NH}_{4}\right)_{0.8} \mathrm{TiOF}_{2.8} \rightarrow \\
\left(\mathrm{NH}_{4}\right)_{0.3} \mathrm{TiOF}_{2.3} \rightarrow \mathrm{TiO}_{2} \\
\left(\mathrm{NH}_{4}\right)_{\mathrm{x}} \mathrm{Fe}(\mathrm{OH})_{3-\mathrm{x}} \mathrm{F}_{2 \mathrm{x}} \rightarrow\left(\mathrm{NH}_{4}\right)_{1-\mathrm{x}} \mathrm{Fe}(\mathrm{OH})_{\mathrm{y}} \mathrm{F}_{4-\mathrm{x}-\mathrm{y}} \rightarrow \\
\left(\mathrm{NH}_{4}\right)_{\mathrm{y}} \mathrm{Fe}(\mathrm{OH})_{\mathrm{x}} \mathrm{F}_{3-\mathrm{x}+\mathrm{y}} \rightarrow \mathrm{Fe}_{2} \mathrm{O}_{3} .
\end{gathered}
$$

Using the data obtained we suggested pyro-hydro-metallurgical method of ilmenite processing [34] which comprises the fluorination of ilmenite with $\mathrm{NH}_{4} \mathrm{HF}_{2}$ at 20-200 ${ }^{\circ} \mathrm{C}$ followed by a simple aqueous leaching of the cake. Combination of hydrolysis and pyrohydrolysis processes gives pigmentary $\mathrm{Ti}$ and Fe oxides. We tried to burn volatile ammonium fluorotitanate in an oxygen atmosphere at $1000^{\circ} \mathrm{C}$ and obtained N-F-doped $\mathrm{TiO}_{2}$ with rutile structure. Crystals with splendid color like sapphire were grown. They are good UVand visible light absorbers. We suspect that selecting conditions of hydrolysis (pyrohydrolysis) or/and pyrolysis of ammonium fluorotitanates, it will be possible to design nanosized N-F-doped $\mathrm{TiO}_{2}$.

Thus, to obtain useful product from natural raw materials using $\mathrm{NH}_{4} \mathrm{HF}_{2}$ we should to take into account that thermodynamically possible fluorination reactions proceed spontaneously (exothermally) with the formation of high symmetry phases of ammonium fluoro- and oxofluorometallates. The essence of high symmetry is dynamic orientation disorder of both ammonium groups and anionic polyhedra.

Under dynamic disorder, it is possible to identify $\mathrm{O}$ and $\mathrm{F}$ atoms on local scale by common X-ray diffraction and to find the real geometry of oxofluoride polyhedron. Orientational dynamic disorder is responsible for PTs at lower temperatures which proceed with rather large $\Delta \mathrm{S}$ and are characterized as PT of order-disorder type.

Oligomerization is the main feature of thermal and hydrolytical decomposition of ammonium fluoro- and oxofluorometallates which can be used for designing perspective functional materials doped by $\mathrm{F}$ and $\mathrm{N}$ atoms.

\section{Acknowledgements}

We thank Dr. A.A. Udovenko, Prof. I.N. Flerov, Prof. V.Ya. Kavun, Prof. S.P. Gabuda and Prof. V.K. Goncharuk for their help and useful discussion.

\section{REFERENCES}

[1] X. Chen, S.S. Mao, "Titanium dioxide nanomaterials: synthesis, properties, modifications, and applications”, Chem. Rev., vol. 107, pp. 2891-2959, June 2007.

[2] H. Tong, S. Ouyang, Y. Bi, N. Umezawa, M. Oshikiri, J. Ye, "Nano-photocatalytic materials: possibilities and challenges", Adv. Mater., vol. 24, pp. 229-251, January 2012.

[3] D. Li, H. Haneda, S. Hishita, N. Ohashi, "Visible-light-driven $\mathrm{N}-\mathrm{F}$-codoped $\mathrm{TiO}_{2}$ photpcatalyst. 2. Optical chracterization, photocatalysis, and potential application to air purification”, Chem. Mater., vol. 17, pp. 2596-2602, Murch 2005.

[4] S. Livraghi, K. Elghniji, A.M. Czoska, M.C. Paganini, E. Giamello, M. Ksibi, "Nitrogen-doped and nitrogen-fluorine-codoped titanium dioxide. Nature and concentration of photoactive species and yheir role in determing the photocatalytic activity under visible light”, J. Photochem Photobiol. A: Chem., vol. 205, pp. 93-97, June 2009. 
[5] X. Du, J. He, Y. Zhao, "Facile preparation of F and N codoped pinecone-like titania hollow microparticals with visible light photocatalytic activity”, J. Phys. Chem., vol. 113, pp. 14151-14158, August 2009.

[6] G.S. Wu, J.L. Wen, S. Nigro, A.C. Chen, “One-step synthesis of $\mathrm{N}$ - and F-codoped mesoporous $\mathrm{TiO}_{2}$ photocatalyst with high visible light activity”, Nanotechnology, vol. 21, No. 085701, February 2010.

[7] Y. Lv, Z. Fu, B. Yang, J. Xu, M. Wu, C. Zhu, Y. Zhao, “ Preparation $\mathrm{N}-\mathrm{F}$-codoped $\mathrm{TiO}_{2}$ nanorod array by liquid phase deposition as visible light photocatalyst”, Mater. Res. Bull., vol. 46, pp. 361-365, March 2011.

[8] W. Wang, C. Lu, Y. Ni, M. Su, W. Huang, Z. Xu, "Preparation and characterization of visible-light-driven $\mathrm{N}-\mathrm{F}-\mathrm{Ta}$ tri-doped $\mathrm{TiO}_{2}$ photocatalyst”, Appl. Surf. Sci., vol. 258, pp. 8696-8703, September 2012.

[9] C. Di Valentin, E. Finazzi, G. Pacchioni, A. Selloni, S. Livraghi, A.M. Czoska, M.C. Paganini, E. Giamello, "Density functional theory and electron paramagnetic resonance study on the effect of N-F codoping of $\mathrm{TiO}_{2}$ ", Chem. Mater., vol. 20, pp. 3706-3714, June 2008.

[10] J. Yu, Y. Chen, A.M. Glushenkov, "Titanium oxide nanorods extracted from ilmenite sands”, Cryst. Growth @ Design, vol. 9, pp. 1240-1244, February 2009.

[11] T. Tao, A.M. Glushenkov, Q. Chen, H. Hu, D. Zhou, H. Zhang, M. Boese, S. Liu, R. Amal,Y. Chen, "Porous $\mathrm{TiO}_{2}$ with a controllable bimodal pore size distribution from natural ilmenite", Cryst. Eng. Com., vol. 13, pp. 1322-1327, March 2011.

[12] G.L. Herwig, “Upgrading titaniferous ores”, Pat. AU No. 428758, June 1972.

[13] A.R. McGregor, A. Rodionov, "F-treatment of titanium materials”, Pat. AU No. 2005100939, February 2006.

[14] S.S. Svendsen, "Manufacture of titanium compounds", Pat. US No. 2042434, June1931.

[15] S.S. Svendsen, "Treatment of titanium-bearing materials", Pat. US No. 2042435, September 1934.

[16] D.M. Chen, Z.Y. Jiang, J.Q. Geng, J.H. Zhu, D. Yang, “A facile method to synthesize nitrogen and fluorine co-doped $\mathrm{TiO}_{2}$ nanoparticles by pyrolysis of $\left(\mathrm{NH}_{4}\right)_{2} \mathrm{TiF}_{6}$ ”, J. Nanopart. Res., vol. 11, pp. 303-313, February 2009.

[17] M. Hojamberdiev, G.Q. Zhu, P. Sujaridworakun, S. Jinawath, P. Liu, J.P. Zhou, "Visible-light-driven N-F-codoped $\mathrm{TiO}_{2}$ powders from different ammonium oxofluorotitanate precursors", Powder Technology, vol. 218, pp. 140-148, March 2012.

[18] L. Zhou, D. Smyth-Boyle, P. O'Brien, “A facile synthesis of uniform $\mathrm{NH}_{4} \mathrm{TiOF}_{3}$ mesocrystals and their conversion to $\mathrm{TiO}_{2}$ mesocrystals", J. Am. Chem. Soc., vol. 130, pp. 1309-1320, January 2008.

[19] L. Zhou, P. O’Brien, “Ammonium oxofluorotitanate: morphology control and conversion to anatase $\mathrm{TiOF}_{2}$ mesocrystals and their conversion to $\mathrm{TiO}_{2}$ ”, Phys. Status Solidy A - Appl. Mater Sci., vol. 205, pp. 2317-2323, October 2008.

[20] M-K. Lee, T-H. Shih, "Growth evolution of ammonium oxotrifluorotitanate discoid crystal on glass prepared by ammonium hexafluorotitanate and boric acid”, J. Phys. D: Appl. Phys., vol.
43, No. 025402, January 2010.

[21] K.L. Lv, J.G. Yu, L.Z. Cui, S.L. Chen, M. Li, "Preparation of thermally sdtable antase $\mathrm{TiO}_{2}$ photocatalyst from $\mathrm{TiOF}_{2}$ precursor and its photocatalytic activity”, J. Alloys Compounds, vol. 509, pp. 4557-4562, March 2011.

[22] L. Chen, L.F. Shen, P. Nie, X.G. Zhang, H.S. Li, "Facile hydrothermal synthesis of single crystalline $\mathrm{TiOF}_{2}$ nanocubes and their phase transitions to $\mathrm{TiO}_{2}$ hollow nanocages as anode materials for lithium-ion battwery", Electrochim. Acta, vol. 62, pp. 408-415, February 2012.

[23] N.M. Laptash, I.G. Maslennikova, L.N. Kurilenko, N.M. Mishchenko, "Ilmenite fluorination by ammonium hydrodifluoride. New ammonium oxofluorotitanate”, Russ. J. Inorg. Chem., vol. 46, pp. 28-34, January 2001 (Translated from Zh. Neorgan. Khim., vol. 46, pp. 33-39).

[24] B.R. Wani, U.R.K. Rao, K.S. Venkateswarlu, A.S. Gokhale, "Thermal behaviour of $\left(\mathrm{NH}_{4}\right)_{3} \mathrm{VO}_{2} \mathrm{~F}_{4}$ and $\mathrm{Na}\left(\mathrm{NH}_{4}\right)_{2} \mathrm{VO}_{2} \mathrm{~F}_{4}$ ", Thermochim. Acta, vol. 58, pp. 87-95, October 1982.

[25] I.G. Maslennikova, N.M. Laptash, T.A. Kaidalova, V.Ya. Kavun, "Volatile ammonium fluorotitanate“, Spectroscopy Letters, vol. 34, pp. 775-781, 2001.

[26] N.M Laptash., I.G. Maslennikova, T.A. Kaidalova, “Ammonium Oxofluorotitanates”, J. Fluorine Chem., vol. 99, pp. 133-137, November 1999.

[27] A.A. Udovenko, N.M. Laptash, I.G. Maslennikova, "Orientation disorder in ammonium elpasolites. Crystal structures of $\left(\mathrm{NH}_{4}\right)_{3} \mathrm{AlF}_{6}$, $\left(\mathrm{NH}_{4}\right)_{3} \mathrm{TiOF}_{5}$ and $\left(\mathrm{NH}_{4}\right)_{3} \mathrm{FeF}_{6}$ “', J. Fluorine Chem., vol. 124, pp. 5-15, November 2003.

[28] A.A. Udovenko, N.M. Laptash, "Dynamic orientational disorder in crystals of fluroelpasolites, structural refinement of $\left(\mathrm{NH}_{4}\right)_{3} \mathrm{AlF}_{6},\left(\mathrm{NH}_{4}\right)_{3} \mathrm{TiOF}_{5}$, and $\mathrm{Rb}_{2} \mathrm{KTiOF}_{5}$ “, Acta Crystallogr., vol. B67, pp. 447-454, December 2011.

[29] I.N. Flerov, V.D. Fokina, A.F. Bovina, N.M. Laptash, "Phase transitions in perovskite-like oxyfluorides $\left(\mathrm{NH}_{4}\right)_{3} \mathrm{WO}_{3} \mathrm{~F}_{3}$ and $\left(\mathrm{NH}_{4}\right)_{3} \mathrm{TiOF}_{5}$ “, Solid State Sci., vol. 6, pp. 367-370, April 2004.

[30] N.M. Laptash, E.B. Merkulov, I.G. Maslennikova, "Thermal behaviour of ammonium oxofluorotitanates (IV)“, J. Therm. Anal. Calorym., vol. 63, pp. 197-204, 2001.

[31] N.M. Laptash, M.A. Fedotov, I.G. Maslennikova, "Hydrolysis of volatile ammonium oxofluorotitanate (IV) according to ${ }^{19} \mathrm{~F},{ }^{17} \mathrm{O}$, ${ }^{49}$ Ti. NMR data“, Russ. J. Struct. Chem., vol. 45, pp. 74-82, January-February 2004 (Translated from Zh. Strukt. Khim., vol. 45, pp. 77-85).

[32] I.G. Maslennikova, N.M. Laptash, A.P. Golikov, "Kinetics of pyrohydrolysis of $\left(\mathrm{NH}_{4}\right)_{2} \mathrm{TiF}_{6}$ и $\left(\mathrm{NH}_{4}\right)_{2} \mathrm{TiOF}_{4}$ “, Russ. J. Inorg. Chem., vol. 46, pp. 186-191, February 2001 (Translated from Zh. Neorgan. Khim., vol. 46, pp. 233-238).

[33] I.G. Maslennikova, N.M. Laptash, A.P. Golikov, "Pyrohydrolysis of ammonium fluoroferrates“, Russ. J. Inorg. Chem., vol. 47, pp. 705-711, May 2002 (Translated from Zh. Neorgan. Khim., vol. 47, pp. 796-802).

[34] P.S. Gordienko, I.G. Maslennikova, N.M. Laptash, V.K. Gonchruk, A.A. Smol'kov, "Method of titanium-containing raw material processing”, Pat. RU No. 2139249, October 1999. 